\title{
The Multi-dimensional Glamour Expressive of The Butterfly
}

\author{
Zhengshun Han \\ Wuhan Textile University \\ Wuhan, China 430073
}

\begin{abstract}
If you happen to watch these movies, like Italian opera movie Madame Butterfly, then French movies: Mr. Butterfly, after that, The Lover, and lastly, The Butterfly, it will surely set you brooding. The writer of this piece is no exception. In his opinion, Madame Butterfly reflects the occidentally-centered pattern, while Mr. Butterfly and The Lover subvert this theme and instead put forth the orientallycentered mode. In this paper, the writer attempts to depict the harmonious relations expressive of the characters in the movie of The Butterfly seeing that all these are generally concerned with love, with its token and symbol of being a butterfly.
\end{abstract}

Keywords-Madame Butterfly; Mr. Butterfly; The Lover; The Butterfly

\section{INTRODUCTION}

It is universally recognized that Chinese classic love story of Liang Shanbo and Zhu Yingtai---equivalent to the western version of Romeo and Juliet-- revolts against the feudalist parents' notion of marital arrangement even at the cost of their lives. After their death for love, a pair of butterflies flying is over their bordering tombs. This beautiful picture, etched on people's mind for ever, always reminds them this symbol of true love and loyal friendship defying all obstacles that come along. Just like it, Madam Butterfly is an opera movie (1904)by Giacomo Puccini about a romantic young Japanese geisha named Cho -Cho-San 'Butterfly' aged 15 , deserted by her husband ---Pinkerton --an American naval officer and heart-collector soon after their marriage (which was actually based on a short story written by John Luther Long in 1898.[1] Although she lives a seclusive life within three years' separation with him, she still clings to the hope that her husband will take her to America. Nevertheless, out of her dire expectation, he comes back with his American wife only to take her son away to America for better opportunities and prosperity. Eventually, she died with grace and elegance with the notion that if one cannot live gloriously, then let her die gloriously, thinking that, in so doing, and with no regret whatsoever, she gives birth to his son---a white man's son, leaving behind him no trouble at all. That's what happened in Japan. Then in China, it is a time-honored tradition that man plays the role of a woman in Beijing Opera. The movie of Mr. Butterfly relates to the story of a French diplomat, tired of his fat, drooping, big-breasted wife, longs for a young, slim and slender lover in 1964 in Beijing. Upon seeing the actress of title role in the Beijing Opera of Madame Butterfly, he is deeply impressed and commences a romantic rapture with his dream woman: a passionate, sexual and exotic affair. After 20 years of romance, he finally comes to know that his shy little "butterfly" turns out to be a handsome guy and thereby turns himself into the laughingstock of the whole French. Consequently, he paints himself as his bride Song Liling on the stage, and cut his throat in cold blood: a European gentleman too refined to notice an illusion or imagination of a cross-dressing temptress."---blinded by his white Western fantasies about a submissive Asian woman. He so desperately required this person to be the butterfly of his dreams that he was simply blind to all other evidence. His self -deception sets the stage for the play's drama, in which the Asian butterfly is victorious, for once, over the visiting European."[2] After that, we come to The Lover by Marguerite Duras, a dauntingly serious French writer, tells the story of an enormously wealthy but extremely bored Chinese man aged 32 seduces a beautiful young French schoolgirl aged 15 in Saigon, Indochina in 1920s." They are made for Each Other." [3] He just simply abuses her as a courtesan for he has to abide by his father's arranged marriage. He pays off all her family debts for his miserable mother and two hostile brothers and finally rejects her who goes back to France to become a successful writer.

Against the backdrop of the 21st century, we have a new French movie named The Butterfly, which is concerned with the harmonious relations among human beings/and nature: love, care and friendship. So the writer hopes to delineate this movie from the following perspectives: (1) Juliet reveals his secrets and searches for his dreams even in his old widowerhood. (2) Elsa's tells her secrets and her search for her lost "identity". (3) The secrets of Isabella have its metaphoric meanings.

\section{JULIET REVEALS HIS SECRETS AND SEARCHES FOR HIS DREAMS EVEN IN HIS OLD WIDOWERHOOD}

In general, butterflies are insects that have large, often brightly colored wings, and conspicuous, fluttering flight. Butterflies, in their adult stage, can live only shortly from a week to nearly a year depending on the species. In art and literature, some are considered to be the reincarnations of the souls of dead: like in Japan, a butterfly is seen as the personification of a person's soul, be they living, dying, or already dead. [4]In this movie, Juliet, the old grandfatherlike figure, has his unique dreams. By occupation, he is a clock-fixer. This manifests itself on two occasions: in the 
opening scene, one woman asks him to look at her clocks; he immediately spots it as the 1962-1964 models, saying that its spare parts go already out of stock, so it cannot be fixed. Then, on his expedition to the mountain, he happens to stay in a farmer's house in a heavy rain. Once inside, he notices a huge clock that hangs on the wall but never works has had a history of 150 years. So you can well see his expertise toward these various clocks.

As for his vast collection of butterfly species and his raising of a large variety of living butterflies in his house, he does it so simply to accomplish his son's dream of seeing one rare species of butterfly----Isabella among a huge album of collections. To keep a promise to his son before his early death at the age of 28 for his swallowing down a bottle of pills due to psychic illness. Juliet failed to do so, and that is a lifelong regret. To compensate for this or receive redemption, he collected a world of species from all over the world. In this movie, he goes on an expedition to the mountain to collect some live Isabellas.

\section{Elsa Tells Her SECRETS AND Her SEARCH FOR HER LOST "IDENTITY"}

Elsa, this worldwise Parisian little schoolgirl, always stay near Juliet's house after school because of her teenage mother's child neglect. On this particular day, she is not given the key to her house, so she ventures into Juliet's home and is told not to open the room of his butterflies. But she defies his warnings and lets out some butterflies. In a fit of rage, she is driven out. But somehow she knows of Juliet's plan of an expedition to the mountains and stays in his car stealthily for attention and adventure. Having never been exposed to the outdoors before, she must lean some hard lessons about nature. On the next day, her mother reports to the police concerning the loss of her daughter, so they start to put on papers and TVs to broadcast the news of hunting for Juliet and Elsa in the meanwhile. When it comes to why her mother always fails to meet her after school, Elsa tells that her mother was raised in an uncared- for manner, she was pregnant at 16 out of accident, and her father deserts them ever since. It is too late for her mother to have the abortion, they live in an impoverished Chinese quarter and she has never been out of town. Therefore, she lacks a lesson about nature. By going on this picnic, she makes up her lesson of interacting with this grandfather-like Juliet and the wild nature: to see huge snails, fishes swimming in the clear streams, cows, deers, butterflies, and to listen to the sounds of winds, bird's chirping and insect singing etc.; to know the evils of illegal hunting, to witness the fragile love, to know the difference between rich and poor, to realize the huge gap between slogans of "liberty, equality and fraternity "and the actual reality, to enjoy the bravery of the strange boy's saving her from a deep hollow pit and so on. These keen observations and their witty dialogue matters most to them both all along are in the movie. That is exactly the seeing point and the tasty parts. All in all, she remains almost an orphan: fatherless and an absentee mother. She demands to be cuddled, cared for and nurtured spiritually ; she needs immediate, subtle, motherly love and care and caution .In the end, after some reeducation by Juliet, both Elsa and her mother learn what to do, and how to behave, they start to act like as being told to be a responsible and faithful mother and a well-bred daughter. What a happy ending, isn't it?

\section{THE SECRETS OF ISABELLA HAVE ITS METAPHORIC MEANINGS}

As is said above, this movie is adapted from the novel entitled The Secrets of Isabella. Here, the writer likes to point out the explicit and implicit metaphorical meanings of Isabella: on the primary level, Isabella refer to this rare butterfly-Graellsia Isabella-that is discovered by a Spanish in 1839, who named it after the Spanish Queen Isabella, which is reckoned as the most beautiful and rare species in Europe, so rare that Juliet once wants to exchange two species that he collected in Peru just for one Isabella. It lives only for three days and nights in the open areas of mountains rising above 5400 feet sea level, with its wings dazzlingly and brilliantly colored as blue and green, with its size being as big as a palm, and its flying time being from dusk to midnight, with the eclosion period being between May and June. Its mating season lasts for only 10 days. Legend has it that if one makes a wish to Isabella, she will carry it to the heaven and it will surely come true. [5]In this movie, the shooting wonder of Isabella's eclosion lasts for four minutes; a treasure moving picture indeed, isn't it?

On the second level, it symbolizes the wishes of Juliet's son upon his deathbed. Juliet spends many years in accomplishing his dream of fulfilling his son's request and he finally succeeds. It can also be said to manifest his deep fatherly love and unwavering commitment to his dead son. On the third level, Isabella is the name of Elsa's mother. Since she is raised up in a kind of indifferent way, so she herself doesn't know how to be a good mother, and is unable to provide motherly love to Elsa, indeed disqualified for being dutiful and responsible. Towards the end, Juliet teaches her the way to be a fit mother: to say three words: I love you every day; to hug her; and let her know that. In so doing, she gets rewarded, too. This even reminds Juliet of his shame being unable to do so while his son is alive. On the fourth level, their expedition and search for Isabella signals their seeking for love and redemption. They go far to seek this happiness and love, only to find it within easy reach of them both. "Where does it fly to?" "It flies to where it is destined to!" This is their happiest dialogue in the end of the movie. Simply put, they find the fatherly love, motherly love, love for nature, and love for friendship, companionship, so on and so forth.

\section{CONCLUSION}

From the above mentioned, it is obvious that butterflyrelated movies occupy a unique place in the world, indeed like no other. If going through the mist of history, we can safely conclude that the opera film of Madame Butterfly reflects the western-dominated conscience of the 19th century while The Lover and Mr. Butterfly subvert this colonial theme and in its place forecast the Orientaldominated mentality after the mid-20th century. In this $21 \mathrm{st}$ century, The Butterfly sets forth the harmonious relations between human and nature, and even among human beings as well: Juliet's fatherly love, Isabella's motherly love, the transcending-age friendship between Juliet and Elsa, their 
love for butterfly, etc. all call for the attention of people, particularly the care and concern of the old and the small; the communication problems of the young which can easily lead to psychic problems. This movie abounds in simple, clear, gripping music, and panoramic view of the country and its lifestyle - the symbol of our soul paradise, and above all, the viewers are immersed in a very strong aura of love, happiness, joy and redemption. It is very hard for one not to be imbued in this harmony. Don't you agree with me?

Oh, Isabella, my Butterfly! To have and to hold so many secrets!!!

\section{REFERENCES}

[1] Madame Butterfly(1915).from Wikipedia, the free encyclopedia.http://en.wikipedia.org/wiki/Madame_Butterfly_(1915fi $\operatorname{lm})$.

[2] M. Butterfly(1993).http://www.rogerebert.com/reviews/m-butterfly1993.

[3] Ken Neth Turan. Movie Review: 'The Lover' Too in Love With Itself: Erotica: French director Jean-Jaques Annaud's film is undercut by an air of self-congratulatory pomposity.Nov.14,1992.http://www.articles. Latimes.com/1992-11-14/entertainment/ca-38_1_french-directorjean-jacques-annaud.

[4] https://en.wikipedia.org/wiki/ The Butterfly.

[5] French film butterfly http://wenku.baidu.com/view/aaf925852458fb770b5694.html. critics. 